\title{
Protection of Individual Privacy under the Continental and Anglo-Saxon Systems: Legal and Criminal Aspects
}

\author{
Saleh Sharari ${ }^{1}$, Raed S. A. Faqir ${ }^{2}$ \\ ${ }^{1}$ Public Relations \& Media, Al-Hussein Bin Talal University, Ma'an, Jordan \\ ${ }^{2}$ Zarqa University Collage, Balqa Applied University, Zarqa, Jordan \\ Email: dr saleh sh@yahoo.com, fageerjo@yahoo.com, fageerjo@bau.edu.joa
}

Received 23 June 2014; revised 19 July 2014; accepted 12 August 2014

Copyright (C 2014 by authors and Scientific Research Publishing Inc.

This work is licensed under the Creative Commons Attribution International License (CC BY). http://creativecommons.org/licenses/by/4.0/

c) (i) Open Access

\begin{abstract}
The present study tries to explain the legal position of privacy in the legal practices of two global different legal cultures: The Continental and Anglo-Saxon systems. This study aims at making sufficient explanation as regard the historical development of the concept and its terminology, and to define the scope of privacy protection and its several forms. Moreover, the study aims to undercover the legal treatment with privacy issues as related to legal protection of dwelling houses, private places, photography, personal communication and conversations, as well as the professional secret's safeguards under both civil and common law systems.
\end{abstract}

\section{Keywords}

Global Legal Systems, Privacy Forms and Scope, Legal and Criminal Protection

\section{Introduction}

The evolution of privacy issues was the result of wide-range of human efforts, which have been contributed by several civilizations. It has been proven that the ancient civilizations of Mesopotamia, the law of Manu in ancient India, legal traditions of Pharaonic Egypt, as well as the practices of Greek and Romanian civilizations all participated in making the formula of the right to privacy. The right to privacy gains a global interest, as a social, moral, democratic, legal and economic value that already international and locally guaranteed in the International Declaration Human Rights and other subsequent international and regional conventions, documents and treaties.

The issue of privacy under both the Continental and the Anglo-Saxon legal systems raises a significant ques- 
tion as to status of the term properly in the composition of fundamental rights in term of two global legal systems. This article tries to answer different questions concerning the legal position of privacy under the two legal cultures: What is the scope of privacy in these legal systems? Is the right to privacy a fundamental right preserved by constitutions under two legal systems? Is there any value of privacy within its terminology? Is the right to individual privacy associated with the right of persons in their homes, private places, pictures and images, correspondences and communications, or is it this concept covers professional secrets under both legal cultures? Could the measures and legal remedies used by two systems are alike, or there may be some differences? To what extent is the privacy protection is applied and guaranteed under penal laws of two legal cultures?

The main objectives of the current article are to explain the historical developments of the right to privacy and to define the term of "privacy" as a legal and social value with taking into account the relativity of the concept through nations, cultures and periods of time. This article aims also to highlight the scope of the right to privacy in comparative laws of both continental system and common law system.

In this study, the focus will be on the issue of privacy protection under both common law systems and civil law systems, and highlights the legal issues concerning the right to privacy under specific legal systems within common law jurisdiction, such those applied in USA and UK, as well as the French legal system as a symbol of the civil law system. The forgoing deep discussion underlines the legal issues concerning protection of several forms and aspects of the right to privacy under the legal systems of those countries, by which the limitation and scope of the privacy regarding the concept of confidentiality and privacy of individuals in their houses, private place, photographs and images, communication and conversations, correspondences, and professional secrets are deeply illustrated.

\section{Right to Privacy: The History and Concept}

\subsection{Origins of the Right to Privacy}

Despite most of legal scholars argue that the legal right to privacy is usually traced back to the late 19th Century (Winn, 2010), the concept of "right to privacy" is found not totally of modern origin, it is traced back to time immemorial. In ancient Mesopotamia, there is evidence that the concept of individual privacy was well known as Article of the Code of Hammurabi (Alexandra, 2013) protected the home against intrusion (Daniel, 2011). The right to privacy was preserved also by the Ishnuna Code of Law, as it imposes harsh penalties for breaches to the individual privacy and the sanctity of dwelling houses of both freemen as well as slaves (Al-Qaisi, 2010).

In ancient India, the concept of privacy has had a deeply traditional concern of both Hindu and Muslims cultures (Basu, 2010). The common features of the right to privacy, such as the privacy of homes, professional secrets and bodily privacy were recognized in ancient civilization of India by the Hindu "Dharmasastras" and the "Arthasastras" and other legal treaties (Lyer, 1999). The same concept has been existed within the old traditions and legal systems of ancient Egypt, as harsh punishments were imposed on people who violate the privacy of homes, holy places and confidential secrets. On this context, it was proved that the old legislations of ancient Egypt contain punishments and penalties for violations of the person's right to privacy (Al. Zawbi, 2004).

In ancient western civilization, an example to the evaluation of the concept of "privacy" was made by ancient Greece, where a known physician called Hippocrates adopted an oath for physicians in order to protect the information and secrets transmitted to them by patients (Keenan, 2005). The legislations of ancient Greece recognized a private domain by making a clear distinction between private sphere of family and public sphere of people, which means that the notion of "privacy" was well known and protected in ancient Greece (Westin, 1967). The notion of "privacy" was mainly based on the idea of refusing to seek or accepting public office, by which anyone who seeks privacy and withdraws into the private space was "no better than the Greek slave, female and child who had no role in public life" (Gondwe, 2011). In ancient Rome, the term of "privacy" was drawn from the Latin words "to be let alone", but the applicability of the essence of this concept was legally designed merely for wealthy statesmen and other people were excluded, as the public and private sphere's spilt was recreated (Schied, 2013).

In present days, the norm of "privacy" becomes a global notion adopted by the constitutions and national laws of nearly every state in the world. The right to individual privacy has been guaranteed also by human rights conventions, including Universal Declaration of human Rights (art.12), the International Covenant on Civil and Political Rights (art.17), the European Convention on Human Rights (art.8), the American Declaration of the 
Rights and Duties of Mean (art. 5, 9, and 10), and the American Convention on Human Rights (art.12), etc. (Banisar, 2011).

\subsection{Definition of Privacy}

In the digital era, the advanced technology imposes new challenges to the personal privacy (Britz \& Ackermann, 2006). In present days, the protection of individual privacy becomes as an essential necessity for democratic societies. Privacy is deeply rooted in the cultural understanding of nations; it differs from one nation to another. For instance, listening to others discourse in private or public places might be deemed a serious privacy breaches in one nation and yet allowed in another. Furthermore, the concept of "privacy" faces lot of difficulties in its definition. The term of "privacy" has been described as something relates to individual autonomy and each individual's control over their data and information (Report of the National Academy of Science, 1993).

Despite the ambiguity of the definition of privacy and the lack of the existing definitions, the nature and scope of this concept should be understood probably in order to clarify the importance of privacy and the necessity of its protection. As a social value, the scope of personal privacy protects all dimensions of human dignity, including human spirituality, psychology and body (Burns, 2001). In legal terminology, the concept of privacy means: "an individual condition of life characterized by exclusion from publicity" (Neethling et al., 2005). As a democratic value, the essential philosophy behind the right to privacy is to protect personal privacy against the intervention of state. And yet, the same value can be violated in present days by private sectors, which impose lot of threats to the personal privacy of individuals. Thus, the broad range of personal privacy can be breached not only by states, but also through private sector intervention (Britz \& Ackermann, 2006).

\section{The Aim and Scope of Privacy}

In today's digital age, the scope of privacy has changed as humans became technologically enhanced persons, especially with repaid developments of cyber and virtual crimes world. These developments impose both positive and negative impacts on the individual privacy, because the new technological devices may be used for more potential privacy breaches. In the present century, all individual liberties and right, including the right to privacy are at jeopardy, and the right to life itself has been placed at challenged or risk.

The individual privacy includes the right of persons to decide whether to hide or reveal their own information. The essence of the right to privacy embodies the notion that each and every person has the right to decide and make clear if, when, and how information can or should be shared with others (Petronio \& Durham, 2008). Nowadays, individual privacy faces lot of challenges due to the growth of technology of computers, internet and GPS devices, as well as the creation of new facilities for electronic surveillance that effect a wide variety of human interests under the umbrella of the term of "privacy" (DeCew, 1986).

The scope of privacy under both Anglo-Saxon systems prevailing in countries such as the United States and the continental system (civil law) symbolized by the French law can be briefly shown as following.

\subsection{In French Legal System}

In France, the scope of privacy includes the private life of persons and personal information related to the field of love life, sexuality, health, religion or finance (Shan \& Pinto 2006). Article 9 of French Civil Code, states that "everyone has the right to respect for his private life", by which the French legislation forbids the publication of photographs against individual's will and consent (Kamm \& Barrett, 1997).

The French jurist Perreau classified the right to privacy under main idea of respect of the individual himself as a citizen and member of family. He advocates that the right of individual can be divided into three groups; these are firstly, rights concerning the recognition of human being, including the use of the name. Secondly, rights related to the "physical individuality", such as the right to life; health; corporal integrity; sacredness of the personal images and pictures and thirdly, rights concerning the "moral individuality" that include rights against breaches to personal freedoms, honor, intellectual work (Wagner, 1971).

On the same context, Nerson, a French jurist, based his theory in clarifying the scope of right to privacy under French legal system on the idea of "patrimony" that defined by him as "totality of property belonging to an individual and of obligations which may be charged against him". According to Nerson, the individual privacy may include the right to one's name, occupation, honor, domicile, moral rights, legal capacity, physical security, right 
against defamation, right to family graves and souvenirs, right to one’s likeness, right to private life, right to happiness, right to love, right to be alone and right to strike [381 US 479, 1965].

\subsection{In US Legal System}

In USA, the right to privacy is not explicitly provided under the US Constitution, but still can be inferred through the First, Third, Fourth, Fifth, and Ninth Amendments of this Constitution. The right of Americans to privacy has been assured by wide variety of cases, as the Supreme Court of USA has admitted the notion of a "Zone Privacy" in Griswold v. Connecticut [429 US 589, 1977], and the motion of the right to privacy was recognized also in Whalen $v$. Roe, as well as it has been recognized by several courts of appeal in the country (Hoofnagle, 2010). The Judicial Aptitude in USA towards "privacy" is based on the theory of Dean Prosser, who advocates that the privacy is composed of four separate elements, which they emerge from the notion of "right to be left alone" (Prosser, 1960). Under US legal system, there are various approaches to the protection of individual privacy that include physical space or things, personal information and protection against the collection and use of personal information; defamation, illegal use of personal names and pictures; interference with personal matters and decisions; family affairs and tapping of telephonic or electronic communication (Levin \& Nicholson, 2005).

In USA, Informational and data protection has been admitted by the Privacy Act of 1974, but the problem with this Act that it was not applied to private sector databases, while the personal information of the drivers is protected under the Driver's Privacy Protection Act of 1994, which was held later unconstitutional by the Supreme Court of USA. Electronic communications of persons is guaranteed under the Electronic Communications Privacy Act of 1986, and protection of family and privacy of student's records in educational institutions against intrusions is safeguarded by the Family Educational Rights and Privacy Act of 1974. On the same context, the financial privacy of persons has been protected under set of legislations in United States of America, such as the Fair Credit Reporting Act of 1970, the financial Modernization Act of 1999 and the Identity Theft and Assumption Deterrence Act of 1998. Personal privacy of individuals is protected by different legislations including the Cable Communication Policy Act of 1984, the Telephone Consumer Protection Act of 1991, the Videotape Privacy Protection Act of 1988, the Telecommunications Act of 1996, the Health Insurance Portability and Accountability Act of 1996 and the Children’s On-line Privacy Protection Act of 1998 (Levin \& Nicholson, 2005).

\section{Forms of the Right to Privacy under Comparative Law}

\subsection{Sanctity of the Home and Private Places}

Right to housing is considered as one of human rights and basic human needs, as it is stated by Miloon Kothari that the right to adequate housing is necessary for each person in order to live in dignity and peace (Report of the Special Rapporteur on the Right to Adequate Housing, 2001). It has been emphasized that the right of persons to have their own homes and houses is well linked with other rights, such as the right to be protected in private life, family and life in general (Annual Reports of the United Nations Special Rapporteur, 2001-2005).

\subsubsection{In France}

Under French legal system, the right of Sanctity of the home and private places is protected by Article 9 of the Civil Code, which states that "everyone has the right to respect for his private life..." This Article ensures the individual privacy in private spheres against violation, as any invasion on one's privacy is considered as a criminal offence. The meaning of dwelling house under French criminal law covers all places used by individuals as private domiciles that may consists private place, rooms in hospitals, ships and hotels, etc. (Al. Zawbi, 2004).

As the inviolability of the home is derived from the right to privacy of the owner, the meaning of housing includes every place where a person resides in permanently or temporarily, and therefore under French legal Jurisdiction the concept of "home" expands to its tabernacle appurtenances, such as gardens and stores, as well it is extended to the private places of residence, even for a limited period of the day, because dwelling house is well known under Article 122 of the French Civil Code as "the principle place where a person set up", while the meaning of dwelling house under the French Penal Code is somehow different, it is broader than in French civil law, it includes every place used by an individual as private zone (Al. Zawbi, 2004). 


\subsubsection{In USA}

In USA, the concept of "dwelling house" is defined under Fair Housing Act as "any building, structure, or portion thereof which is occupied as, or designed or intended for occupancy as, a residence” (42 U.S.C. § 3602(b), 2006). Thus, it can be inferred out of the American law's definition that the term of "dwelling house" includes only traditional dwellings, such as apartments, family houses, trailers, mobile home parks, cooperatives, condominiums, courts and time-sharing properties, and excludes properties such as motels and hotels from the scope of private homes or places (Wong, 2009). Under the legislation of North Carolina, the term of "dwelling house" means "any building, structure, manufactured home or mobile home, or part thereof, used and occupied for human habitation or intended to be so used, and includes any outhouses and appurtenances belonging thereto or usually enjoyed therewith, except that it does not include any manufactured home or mobile home, which is used solely for a seasonal vacation purpose” [North Carolina General Statutes § 160A-442]. American jurisdiction and courts in deciding the dwelling nature of places and spaces of relies on many factors such as "the normal length of stay intended by the facility, the institutional or residential nature of the facility and whether the purpose of the facility to provide housing, or whether housing is linked to some broader purpose" [North Carolina General Statutes § 160A-442].

\subsubsection{In UK}

In UK, the legal meaning of the term of "dwelling house" is "a self-contained 'substantial' unit of accommodation, such as a building, part of a building, caravan, houseboat or other mobile home. A tent is not normally be considered to be substantial”. Sections 115-118 of the Income Tax Assessment Act 1997 defines the dwelling house as "a) a unit of accommodation that: 1) is a building or is contained in a building; and 2) consists wholly or mainly of residential accommodation; and b) a unit of accommodation that is a caravan, houseboat or other mobile home; and c) any land immediately under the unit of accommodation. However, except as stated in Sections 118-120 of the same Act, dwellings may not cover any land adjacent to a building (Sect 118.115).

\subsection{Right to Photographs}

The legal protection of the individual right to photographs is designed against the publication of person's images, photos and pictures without his or her consent. Accordingly, the legal protection to personal images, pictures and photos is decided against the illegitimate usage and publishing of people pictures, which may destroy the legal, physical and moral interests of individuals in such pictures and photos (Verbauwhede, 2014).

\subsubsection{In France}

Under French legal system, the right of persons to photographs is generally guaranteed by article 9 of Civil Code, thus the use or publication of people's photos or images without their prior permission is forbidden under French law. Practically, the right to photographs in France is actionable for the private photos and images of persons, while publicly known pictures, images and photos of public figures under French law is not guaranteed against publication or usage of media and other means. French legal jurisprudence in its opinion towards the right to photographs is divided into trends; some of the legal scholars agree that this right as one of personality rights, therefore "the separate tight to likeness photographs of public men can be used...for no other purpose than to illustrate events in which they were involved. This use is based on their implied consent” (Wagner, 1971).

\subsubsection{In UK}

The Right to Photographs is guaranteed under both British Human Rights Act of 1998, which makes some restrictions on publication of personal images, pictures and photographs. The European Convention on Human Rights also is applied in UK, as its 8 in contrary to Article 10 protects this right and courts will consider the communal interest in balancing the rights by the legal check of proportionality. Some other British legislation safeguards the right to photographs and prohibits its publication without the consent and permission of their owners, such as the Copyright Designs and Patents Act 1988. (Hendrickx, 2002)

In Britain, it is illegal to take photographs of children in public spaces (Protection of Children Act, 1978), or to publish or communicate a photograph of a member of the armed forces, or a member of the security services (Counter-Terrorism Act, 2008). Section 58 of the Terrorism Act 2000 penalizes the act of taking a photograph of a kind likely to be useful to a person committing or preparing an act of terrorism, or possessing such a photo- 
graph. Under the British Copyright, Designs and Patents Act 1988, some types of photographs may not be safeguarded by copyright, and it is up to courts to decide the copyright which subsists in works on the grounds of public interest (Section 171(3)). In the case of Creation Records, it has been ruled that "the newspaper photographer did not infringe the official photographer's copyright. Copyright did not subsist in the scene itself-it was too temporary to be a collage, and could not be categorized as any other form of artistic work" (Creation Records Ltd. v News Group Newspapers Ltd. (1997) EMLR 444 (Ch)).

\subsubsection{In USA}

The right to photograph under the US legislation emanates from both ideas of economic exploitation and privacy. On the same context, the right of persons in their photographs is the right that designed for all persons against illegitimate and undue commercial use of their images, pictures and photographs; it is also recognized under US law as one of the personality rights. Under Indiana law, the right to photograph is well recognized for every individual, where people are protected even after their death in their "names, images, likeness and photographs". In California, the protection of person's right to photograph is ensured by both common law and statutory, and under the Celebrities Rights Act of California, 1985 it is protected not only as one aspect of the right to privacy, but also as a property right which makes it as transferable to heirs in case of inheritance after the death of the owner of this right.

In the case of Galella V. Onassis [487 F.2d 986 (2nd Cir. 1973)], the court has assured that the right to privacy includes: “a general 'right to be left alone', and to define one's circle of intimacy; to shield intimate and personal characteristics and activities from public gaze; to have moments of freedom from the un-remitted assault of the world and unfettered will of others in order to achieve some measure of tranquillity for contemplation or other purposes, without which life loses its sweetness” (namheL, 1982).

\subsection{Privacy of Personal Conversation}

The protection of personal conversations is a significant aspect of the person's right to privacy, which means that each person has the right to be protected against undue invasion to the privacy of his or her conversation. This right covers the protection of the privacy of personal conversation against any eavesdropping of such conversation made either by laymen or official authorities. Every person has the right to privacy in his own telephonic conversations against any illegal and arbitrary records. Thus, call records are prohibited unless carried out by the concerned agencies, such as police or investigating officers and upon the consent of the party as well as within the sanction of the concern authority (Mushasha, 2013). The individual privacy sold telephone conversation, either made in office, home, public or private place can be violated by tapping it. However, this right is not an absolute one where many restrictions may be imposed on it even in the democratic countries for the purposes of security, intelligence or investigation (Ismail, 2013). The act eavesdropping can be done through instant messaging, email, telephone lines and other means of communication viewed as private conversation (Ahmed, 2009). Listening to telephonic conversation is called "phone tapping", which means the secretly monitoring of conversations made through telephone and internet with the purpose of having information and knowledge about the transmitted conversations and/or altering them (Canadian Personal Information Protection and Electronic Documents Act, S.C. 2000, c.5).

\subsubsection{In France}

The French Wiretapping Act of 1991 aims at safeguarding the individual right to privacy in "secrecy of messages transmitted by way of telecommunications", especially with fact that the law permits the public authorities to conduct wiretapping for national security and law enforcement purposes (Kilkelly, 2001). Here, it should be noticed that the wiretapping of transmitted conversations through telephone lines or e-mails under French law can be conducted for criminal investigation and law enforcement purposes only upon judicial authorization, but it dose require merely the prior permission of Prime Minister when wiretapping is conducted for national purpose (Tomlinson, 1993). At the criminal investigation stage, the judge has a discretionary power to interview any person's telephonic conversation upon the aid of the police agency and to order telephone tapping, Article 81 of the Code of Criminal Procedure grants the magistrate wide powers to wiretap (Ministry of Justice, 2014). Finally, it is obvious the French legislation makes wiretapping and electronic eavesdropping as illegal acts in case of revealing any information related to an individual's sexual life or private finances, but still it is legal act if conducted within 
the purposes of Article 368 of the Penal Code for both law enforcement and national security purposes.

\subsubsection{In USA}

The violation of the right to privacy of one's telephone conversation is criminalized as a second degree felony under Taxies law and punishable with imprisonment, the same offence is panellized under the federal law in USA with fine and/or jail of up to five years (Tex. Penal Code Ann. 16.02 (1); Collins 904 S.W.2d at 792, 18 U.S.C. \& 2511 (4) (a)). Finally, the power of investigator during criminal investigation is restricted under American law in making any secret videotape to any subject without his or her consent or knowledge during that time, and it will be dealt with as an inadmissible in Court of Law (Ismail, 2013).

The Supreme Court of USA has assured that the wiretaps are not a type of search, and therefore it can be done without any need to hold a search warrant. However, Justice Louis Brandeis advocates that the wiretap constitutes a special form of search, and the invasion to "privacy of telephone is far greater than that involved in tampering with the mails [Olmstead v. United States, vol. 277, US Supreme Court, p. 438, 1928]. In Brandeis's view of point, the telephonic conversation of persons irrespective of its subjects should be always confidential, and any tapping made to them even by police should be considered as invasion against personal privacy unless was based on law and upon a special warrant. In Katz v. United States, it has been held by the court that the principles and rules of the Fourth Amendment are designed to protect people and not places [Katz v. United States, 389 US at 351], such judgment made by the Katz Court has altered later the jurisprudential and judicial trends towards the issue of wiretapping in USA (Saperstein, 1956). Most U.S. courts agreed on the base of the inadmissibility of the warrant-less tapping by federal agencies, and the results of such tapping are not deemed as approvable evidence in the Court of Law [Nardone v. United States, 302 US 379 (1937), see also Weiss v. United States, 308 US 321 (1939)].

\subsubsection{In UK}

In UK, the legality of wiretapping of personal discourses and conversations by police agency was highlighted in the case of Malone v. Metropolitan Police Commissioner, the court found that the practice of wiretapping does not require a prior approval from the Secretary of State as it involves no act of trespass, as well as the legality of telephone tapping can be firstly decide by the Parliament, and not the courts [Malone v. Metropolitan Police Commissioner, [1979] Ch. at 369]. The English wiretapping rules were held by the European Courta as violative to the Article 8 of the European Convention on Human Rights (ECHR) [51]; as such those rules are ambiguous, because they have not specified the scopes, manners and purposes of practicing of wiretapping by concerned authorities in Britain [Malone case, 82 Eur. Ct. H.R. (Ser. A) 1984].

\subsection{Privacy of Personal Correspondences}

The concept of personal correspondence implies the notion of communication of feelings and thoughts to friends, relatives and someone else through exchange of letters (DeVito, 2002). Thus, it can be said that correspondence is a written or digital communication, which may reflect ideas, thoughts, affairs, information beliefs, and opinions or feelings by two or more parties. Moreover, personal correspondences may be defined as a written or electronic means by which one's views are expressed and transmitted to other party (Serbanescu, 2014). Correspondence may include postal correspondence, text messages, notes, emails, postcards or voicemails telephone calls, e-chatting trough face book, twitter and any other internet networks [Golders v. the United Kingdom [1975] 1 EHRR 524, and Halford v. the United Kingdom [1997] 1424 EHRR 523]. The right to privacy of personal correspondences is protected under both Anglo Saxony legal and continental systems against any type of interference, such as reading, opening, deleting or censoring of those correspondences [McCallum v. the United Kingdom [1990] 13 EHRR 596; Campbell v. the United Kingdom [1992] ECHR 13590/88].

\subsubsection{In France}

In France, a long to other fundamental rights, such as the right to inviolability of homes, fair trial and confidentiality of communications, the right to privacy of secrecy of personal correspondences and letters are guaranteed by the government to its citizen (Edward, 2013). Presently, the criminal legislator in France provides a protection to secrecy and privacy of individual correspondence, on this context, Article 226-15 of the Criminal Code reprimands "all actions likely to deprive the addressee, even momentarily, of the correspondence addressed to 
him” (Hill \& Allnutt, 2012). Under French legal system, information contained in personal correspondences is considered private and are thus legal safeguarded as private matters if it is not publicly available. Consequently, as long as information on a person is private and the collection of such information may involve the infringement of the right to personal privacy or correspondence, and any third parties are not legalized to reveal such information (Horne \& Konstantinou, 2012).

Upon the reading of Articles 81 and 151 of the Code of the French Criminal Procedure, and Article 66 of the French Constitution of 1958, it is found that the right to privacy of personal correspondences is not an absolute right. This right can be violated on the basis and "in accordance with law". Article 81 of the Code of Criminal Procedure is interpreted in away that to authorize the magistrate to take all the necessary actions in order accomplish investigation, including the seizure of personal correspondence of letters and mails in the post offices (Tomlinson, 1993). The French Court of Cassation has constantly denounced a seizure made upon the authorization of a magistrate to the personal correspondence between an accused and lawyer and presently powerfully generalized that prohibition to the act of tapping oral communications [Judgment of April 15, 1991, Cass. crim., 1992 J.C.P. Jur. No. 21795].

\subsubsection{In USA}

In USA, despite the right to privacy is not guaranteed explicitly under the Constitution, the Supreme Court has recognized this right as a constitutional right within a limited and narrow interpretation of the Bill of Rights and its amendments. The privacy of personal correspondences is ruled as part of the general right to privacy, and it is guaranteed against the surveillance of public authorities as a person has a "reasonable expectation of privacy (Roberto, 2001), but still this right needs a protection by applying a specific law (Coles, 1991). The Privacy Act of 1974 is applied to the protection of personal correspondences held by US Government authorities, such as post office (codified at 5 U.S.C. § 552a (1988)). Under American legal system, the surveillance of written and electronic correspondences for criminal investigations is regulated by both the electronic Communications Privacy Act, 1986 and a special Act of Omnibus Safe Streets and Crime Control, 1967 (Doyle, 2012). The powers of police officers in USA is not absolute in opening or reading personal correspondences, and no information or data to be collected or obtained out of these correspondences without the court order established on the necessary legal requirements, while in case of investigation for national security purposes such order can be based on lesser numbers of requirements under the Foreign Intelligence Act, amendment of 1994 [Foreign Intelligence Surveillance Act of 1978, 50 U.S.C. 1801].

\subsubsection{In UK}

As part of the right to privacy, the secrecy of the personal correspondences was not protected explicitly under English law, but the enactment of the Human Rights Act 1998 paved the path for a foundation of the general right to privacy and protection of the secrecy of personal correspondence in particular. The general as aspects of the right to privacy, as well as the confidentiality of personal information transmitted in the individual correspondences were protected since long time in the common law along with wide spectrums of other interests.

Despite the fact that the new legislations in UK and the common law safeguards the personal right to secrecy of correspondences, but still there are several pieces of legislation authorize police officers and other agencies of public authorities to interfere with this right. The UK is a member of many international conventions that provide for protection of private life, family, data and information privacy. By incorporate the European Convention of Human Rights into UK domestic law, a clear picture of the right of privacy has been well established. The protections of the right to privacy in general, and its aspects related to the protection of confidentiality of personal correspondences, private and family life, have been ensured under Article 8 of the convention. The current position of the right to privacy and personal data and information in UK is well guaranteed under various laws, such as the regulations of investigatory Powers Act of 2002, the Gender Recognition Act of 2004, the Mental Capacity Act of 2005 and the Health and Social Care Act, 2008.

\subsection{Privacy of Professional Secrecy}

The term of "professional secrecy" has been recognized over centuries in most of legal systems all over the world. The professional confidentiality, privilege or secrecy is considered as a fundamental concept of the achievement of justice. It is designed for the protection of information disclosure that already exchanged in the term of profession, such as the information transmitted by the client to his lawyer (Spronken \& Fermon, 2008). 
The concept of "professional secrecy" is used under the civil law system (continental Europe system), while the term used under common law systems is "professional privilege", the two notions under both systems are similar, but the concept of professional secrecy or confidentiality is wider in scope than a privilege. It covers information exchanged between lawyers and their clients on the basis of judiciary or contractual relationship (Burdette, 2010). Thus, it can be said that under common law system, the professional privilege covers two types of communications, firstly lawyer-client's communication in term of giving or obtaining legal device privilege, and secondly lawyer-client's communications or communications made between the lawyer and client with other third parties with the aim of preparing for legal proceeding (Mačák, 2014). In contrary to the common law systems, the legal professional confidentiality or secrecy under civil law systems (continental Europe) cannot always be waived by the client, which means that the legal practitioner (advocate or lawyer) has no legal power to reveal or disclose the secret information supplied to him by his client (Edward, 2003).

\subsubsection{In France}

In France, the professional secrecy is protected by the statute, such as Article 160 of decree 27 November 1991, and Article 66-5 of law of 31 December 1971, modified by law 7 April 1997. The protection of professional secrecy under French criminal law is not unlimited, the Court of Cassation (criminal chamber) for example, has emphasized that the professional secrecy does not exist in case of its usage for illegal interests (Cass. Crim. 12 March 1992), moreover it has been decided by French Court that a lawyer may disclose secret information of his client in case of necessity for the protection of the custodian of secret from unjustified potential accusation (Cass. Crim. 29 May 1989, Bull. Crim. no 218). Under the French legislation, the obligation of keeping professional secrecy undisclosed in some circumstances related to the protection of a lawyer himself from accusation based on the relationship with his client, and in case police seizing of a document containing professional secrets in order to prove the participation of lawyer in the breach of law and in matters of legal counselling [Criminal chamber of the Appeal Court 29 May 1989, Criminal chamber of the Appeal Court 12 March 1992 and Criminal chamber of the Appeal Court 30 June 1999].

\subsubsection{In USA}

Under American legal jurisdiction, the concept of professional confidentiality consist two notions; it is a right for a client and a privilege for a lawyer. It is the client's right to deny to uncover or expose secret and privileged communications between lawyer and client for the objective of obtaining legal advice or counsel [Fisher v. United States, 425 US 391, 403, 1976]. The right of professional secrecy is established to ensure the corned relationship between the lawyer and his client, as the legal device itself relies entirely on the information transmitted by the client about his case. This right makes it the duty of the lawyer to abstain from disclosing any privileged information exposed by his client. Furthermore, this guarantee prohibits any other persons, including the lawyer, from using any connections or information that may be deemed a "professional confidentiality" for evidential purposes in the court of law [Upjohn Co. v. United States, 449 US 383, 389 (1981)]. Despite, the professional privilege is not wider in scope than the attorney's ethical duty of secrecy; it truly grants broader protective safeguards for the relevant connections [Upjohn Co. v. United States, 449 US 383, 389 (1981)]. On the other side, the professional confidentiality is considered as a privilege for the lawyer, by which the lawyer has a duty to work loyally and seriously on behalf of the client. The duty of secrecy requires from the lawyer not to disclose any information falling within the confidence limits to any other party (Christensen, 2011).

\subsubsection{In UK}

In UK, the legal basis for protection of professional privacy, the connections, correspondences, conversations and secrets exchanged or transmitted by patient to his doctor, client to his lawyer etc., is found in rules of law, and not in the rules of professional conduct. The English law imposes obligations upon professionals for not disclosing any secret information submitted or transmitted to them in term of exercising of their duties and professions, and refraining from given a evidence on issues or facts covered by those secrets, as the disclosure of professional secrecy is considered a violation to the provisions of the Penal Code, by which this act is an offence punishable with imprisonment or a fine or both (Edward, 2003). The significance of the professional privilege in UK has been emphasized and recognized by House of Lords as an essential part of the fundamental right of access to legal practitioner, as well as right to defense [R. v Derby Magistrates Court, Ex p. B. [1996] 1 AC 487; Special Commissioner and Another, Ex p. Morgan Grenfell and Co Ltd [2002] 2 WLR 1299; [2001] 3 AER 1; R 
v Secretary of State for Home Department, Ex p. Daly [2001] 3 AER 433; [2001] 2 WLR 1622]. Privacy of professional secrecy is not an absolute right under English law, as it has been ruled by courts that the legal professional confidentiality or privilege concerning a communication made between the client and his lawyer in the form of advise for the commission a crime is not falling within the protection designed for professional privilege, as well as the act by itself is illegal and criminal [Micosta SA v Shetland Islands Council 1983 SLT 483]. The protection of professional privilege is limited also under Revenue law, as well in cases concerning money laundering (Edward, 2003).

\section{The Evaluation of the Privacy Status under Common Law Systems and Civil Law Systems}

\subsection{The Legal Dimensions of Privacy in Civil Law Countries: The Case of France}

From criminal law prospective, the French legislature deals seriously with the issue of breaching the personal privacy, and has criminalized acts of recording and filming of the intimacy of the private life of people including recording or transmitting their conversations, pictures, images. The acts of spying and photographing of private life and matters without the consent of others are prohibited in France as a violation to individual privacy. Posts and telephone correspondences as integral essence of the individual privacy are guaranteed in France against illegal invasion (art. 8 of the ECHR). The family housing and domicile under French Civil Code is well protected also against spying or any type of invasion on its security and peace (arts. 675-680), moreover the French Penal Code guarantee the individual privacy in domicile by criminalizing the act of the penetration or unlawful occupation of others houses and private places (art. 226 (4)) and imposes harsh penalty for using violence for such violation (art. 432).

The civil law systems are very sensitive about the protection of personal privacy even in public places, where the surveillance rules in France allow the use of cameras in public places for the purposes of security monitoring under the stipulation of not breaching person's privacy. Moreover, it has been discussed earlier that the personal image, name and voice are essential parts of person's privacy, and all those are real protected values by French law against undue and illegal intervention or violation. The legal remedies for the violation of the individual privacy of ordinary or public figure citizens or foreigners (art. 8 and 14 of the ECHR) are made by compensation or criminal prosecution, or by facing two remedies together (art. 9 of the French Civil Code).

\subsection{The Legal Dimensions of Privacy in Common Law Countries: The Case of USA and UK}

Based on the abovementioned discussion, it can be said that the common law countries including UK use some specific legal remedies in dealing with the violations and breaches of individual privacy. Legal remedies for the protection of privacy interests already used by courts in Britain are made upon tortuous liability. The scope of protecting privacy in Britain is not limited to the parties of contracts, but covers also personal confidences, commercial data and governmental information.

The scope of privacy protection under common law systems is somehow wider than its counterpart of civil law system, as in common law it covers defamation, trespass, copyright, nuisance, negligence, breach of contract, and breach of confidence etc. In USA, the legal mechanism adopted for protecting privacy interests are clearer than those applied in UK, where individual privacy is guaranteed through the enactment of new torts of infringements of privacy, recognition of constitutional principle concerning privacy, as well as the utilization of special legislative procedures and measures at both federal and state levels. On the same context, it is found that the people enjoy the same level of privacy protection in Britain, while in USA the privacy protection of laymen seems to be greater than the protection granted to public figures.

\subsection{Comparison of the Privacy Status under Common Law Systems and Civil Law Systems}

In comparison, the developments of the rules governing issues of privacy under common law systems is considered more pragmatic than the progress of those rules under civil law systems, as privacy rules under common law are created and made by judges on the basis of the developments in different aspects of modern life, while in civil law countries these rules are enacted by legislative power in the codified form. Most of civil law countries have not recognized the protection of privacy as a constitutional right, but at the same time such countries have their own special legislation for protection of personal information and data as well as other privacy related laws, 
in contrary common law countries protect privacy issues on the basis of constitutional doctrines.

Finally, it can be said that there are some similarities between both legal systems in term of the measures and procedures taken by special institutions established under common and civil laws for the protections of various aspects of privacy interests and prevention of any potential harms against them.

\section{References}

Ahmed, M. H. (2009). Threats to Mobile Phone Users' Privacy, a Project Report. St. John’s, NL: Memorial University of Newfoundland. http://www.engr.mun.ca/ mhahmed/privacy/mobile phone privacy report.pdf

Al. Zawbi, A. A. A. (2004). The Right to Privacy in Criminal Law: Comparative Legal Study. Ph.D. Thesis, Mosul: Faculty of Law, University of Mosul.

Alexandra, R. (2013). Privacy in the 21t Century. Leiden: Koninklijke Brill NV.

Al-Qaisi, N. (2010). Role of Ancient Iraqis in the Invention of the Shekel (in Arabic). Ma'altha Quarterly, 4, 4.

Annual Reports of the United Nations Special Rapporteur on the Right to Adequate Housing to the Commission on Human Rights (2001 to 2005) and to the Human Rights Council (since 2006): E/CN.4/2001/51, E/CN.4/2002/59, E/CN.4/2003/5, E/CN.4/2004/48, E/CN.4/2005/48, E/CN.4/2006/41, A/HRC/4/18.

Banisar, D. (2011). The Right to Information and Privacy: Balancing Rights and Managing Conflicts. Washington DC: The International Bank for Reconstruction and Development/The World Bank.

Basu, S. (2010). Policy-Making, Technology and Privacy in India. The Indian Journal of Law and Technology, 6, 65-88.

Britz, H., \& Ackermann, M. (2006). Information, Ethics and the Law. Van Schaik: Pretoria.

Burdette, M. (2010). Is the Reporting Obligation of Attorneys in Terms of Section 29 of the Financial Intelligence Centre Act 38 of 2001 a Myth or a Reality? Unpublished LLM Dissertation, Pretoria: University of Pretoria.

Burns, Y. (2001). Communications Law. Durban: Butterworths.

Christensen, L. M. (2011). A Comparison of the Duty of Confidential and the Attorney-Client Privilege in the US and China: Developing a Rule of Law. Thomas Jefferson Law Review, 34.

Coles, T. R. (1991). Dose the Privacy Act of 1974 Protect Your Right to Privacy? An Examination of the Routine Use Exemption. The American University Law Review, 4.

DeCew, J. W. (1989). The Scope of Privacy. Law and Philosophy, 5, 145-173.

DeVito, J. A. (2002). Human Communication, Unite One, Part One Foundations of Human Communication. Boston, MA: Allyn \& Bacon.

Doyle, C. (2012). Privacy: An Overview of the Electronic Communications Privacy Act. CRS Report for Congress Prepared for Members and Committees of Congress. https://www.fas.org/sgp/crs/misc/R41733.pdf

Edward, Q. C. (2003). The Professional Secret, Confidentiality and Legal Professional Privilege in Europe, an Update on the Report by D.A.O. Edward, QC, the Council of Bars and Law Societies of Europe (CCBE).

http://www.europarl.europa.eu

Edward, Q. C. (2013). The Professional Secrets, Confidentiality and Legal Professional Privilege in the Nine Members States of the European Community, the Faculty of Advocates in Scotland. http://www.europarl.europa.eu

Gondwe, M. (2011). The Protection of Privacy in the Workplace: A Comparative Study. Ph.D. Thesis, Stellenbosch: Faculty of Law, Department of Mercantile Law, University of Stellenbosch.

Hendrickx, F. (2002). Protection of Workers' Personal Data in the EU: General Issues and Sensitive Data. http://ec.europa.eu

Hill, P., \& Allnutt, H. (2012). International Data Breach Law: A Comparative Guide. Canadian Litigation Counsel, The Harmonie Group.

Hoofnagle, C. (2010). New Challenges to Data Protection Country Study B.1-United States of America. In D. Korff (Ed.), Comparative Study on Different Approach to New Privacy Challenges, in Particular in the Light of Technological Developments, Submitted by LRDP KANTOR Ltd. (Leader).

http://ec.europa.eu/justice/policies/privacy/docs/studies/new_privacy_challenges/final_report_country_report_B1_usa.pdf

Horne, S., \& Konstantinou, E. (2012). Social Media and International Employment. In The Employment Law Review (3rd ed.).

Ismail, S. M. (2013). A Critical Analysis on Telephone Tapping Conversation. Research Journal of Computer and Information Technology Sciences, 1, 1-6.

Kamm, T., \& Barrett, P. M. (1997). The Legal Picture: How Would Paparazzi Who Stalked Diana Fare in French Court? Wall Street Journal.

Keenan, K. M. (2005). Invasion of Privacy. In Library of Congress Cataloging-in-Publication Data. 
Kilkelly, U. (2001). The Right to Respect for Private and Family Life: A Guide to the Implementation of Article 8 of the European Convention of Human Rights. Human Right Handbook, No. 1. Germany: Council of Europe.

Lehman, G. D. (1982). Invasion of Juror Privacy. http://www.unmarriedamerica.org/Archives/1980-1982-Privacy-Commission/1982-PPC-Supplement-3-b.pdf

Levin, A., \& Jo Nicholson, M. (2005). Privacy Law in the United States, the EU and Canada: The Allure of the Middle Ground. University of Ottawa Law \& Technology Journal, 2, 357-395.

Lyer, V. R. K. (1999). The Dialectics and Dynamics of Human Rights in India: Yesterday Today and Tomorrow, Tagore Law Lectures. New Delhi: Eastern Law House.

Mačák, K. (2014). That’s a Secret I Must Keep to Myself, Your Honor! Comparative and Theoretical Assessment of Legal Professional Privilege in England and on the Continent, the Common Law Review. http://www.commonlawreview.cz

Mushasha, M. K. (2013). Proving the Crime by Scientific Evidences. Law Faculty, United Arab Emirates University. Journal of Sharia and Law, 27.

Neethling, J., Potgieter, J. M., \& Visser, P. J. (2005). Neethling's Law of Personality. Durban: Butterworths.

Petronio, S., \& Durham, W. T. (2008). Communication Privacy Management Theory. In L. A. Baxter, \& D. O. Braithwaite (Eds.), Engaging Theories in Interpersonal Communication: Multiple Perspectives. Thousand Oaks, CA: Sage.

Prosser, W. L. (1960). Privacy. California Law Review, 48, 383-423. http://dx.doi.org/10.2307/3478805

Report of the National Academy of Science (1993). Panel Report Private Lives and Public Policies. Washington DC: National Academy of Science.

Report of the Special Rapporteur on the Right to Adequate Housing to the 57th Commission on Human Rights, E/CN.4/ 2001/51, § 8, 25 January 2001.

Saperstein, D. (2008). The European Counterterrorist as the Next US Cold Warrior: Why the United States Should Select from the German and British Models of Procedure, Evidence, and Oversight for National Security Wiretapping. Fordham International Law Journal, 32.

Schied, J. (2013). Politics and Religion in Ancient Rome. Translated by Eric Rosencrantz, the Institute du Monde Contemporain. http://www.booksandideas.net/Politics-and-Religion-in-Ancient.html

Serbanescu, T. (2014). Personal Communication: An Interactive Qualifying Project Analyzing the Use and Effects of Personal Communication in the Modern Age. A Project Study for the Bachelor of Science Degree, Faculty of Worcester Polytechnic Institute. http://www.wpi.edu/Pubs/E-project/Available/E-project-090311-151245/unrestricted/Personal Communication IQP.pdf

Shan, N., \& Pinto, T. (2006). Defamation and Privacy Law and Procedure in England. Germany \& France: Taylor Wessing. www.taylorwessing.com

Spronken, T., \& Fermon, J. (2008). Protection of Attorney-Client Privilege in Europe. Penn State International Law Review, 27, Issue 2, 349.

Tomlinson, E. A. (1993). The Saga of Wiretapping in France: What It Tells Us about the French Criminal Justice System. Louisiana Law Review, 53, 1091-1152.

Verbauwhede, L. (2014). Legal Pitfalls in Taking or Using Photographs of Copyright Material, Trademarks and People. http://www.wipo.int/export/sites/www/sme/en/documents/pdf/ip_photography.pdf

Wagner, W. J. (1971). The Development of the Theory of the Right to Privacy in France. Washington University Law Quarterly, 45, 195-227. http://digitalcommons.law.wustl.edu/lawreview/vol1971/iss1/13

Westin, A. F. (1967). Privacy and Freedom. New York: Atheneum.

Winn, P. A. (2010). Older than the Bill of Rights: The Ancient Origins of the Right to Privacy. http://ssrn.com/abstract=1534309

Wong, K. (2009). Narrowing the Definition of Dwelling under the Fair Housing Act. UCLA Law Review, 56, $1866-1899$. 
Scientific Research Publishing (SCIRP) is one of the largest Open Access journal publishers. It is currently publishing more than 200 open access, online, peer-reviewed journals covering a wide range of academic disciplines. SCIRP serves the worldwide academic communities and contributes to the progress and application of science with its publication.

Other selected journals from SCIRP are listed as below. Submit your manuscript to us via either submit@scirp.org or Online Submission Portal.
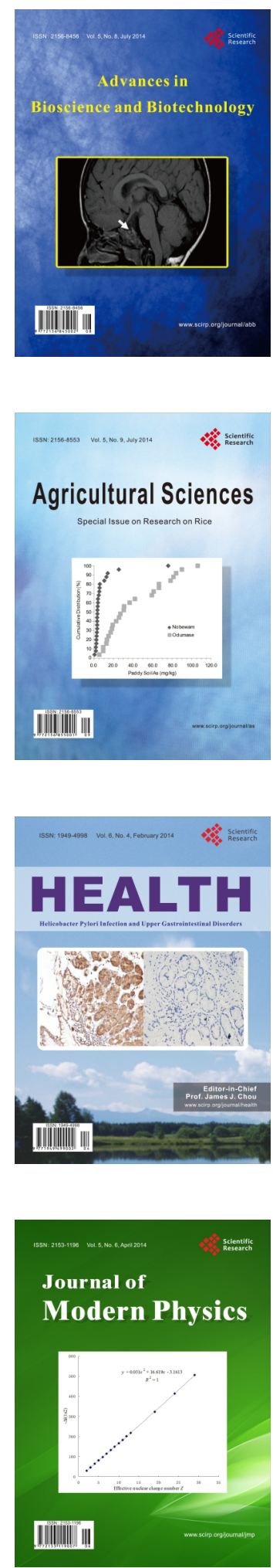
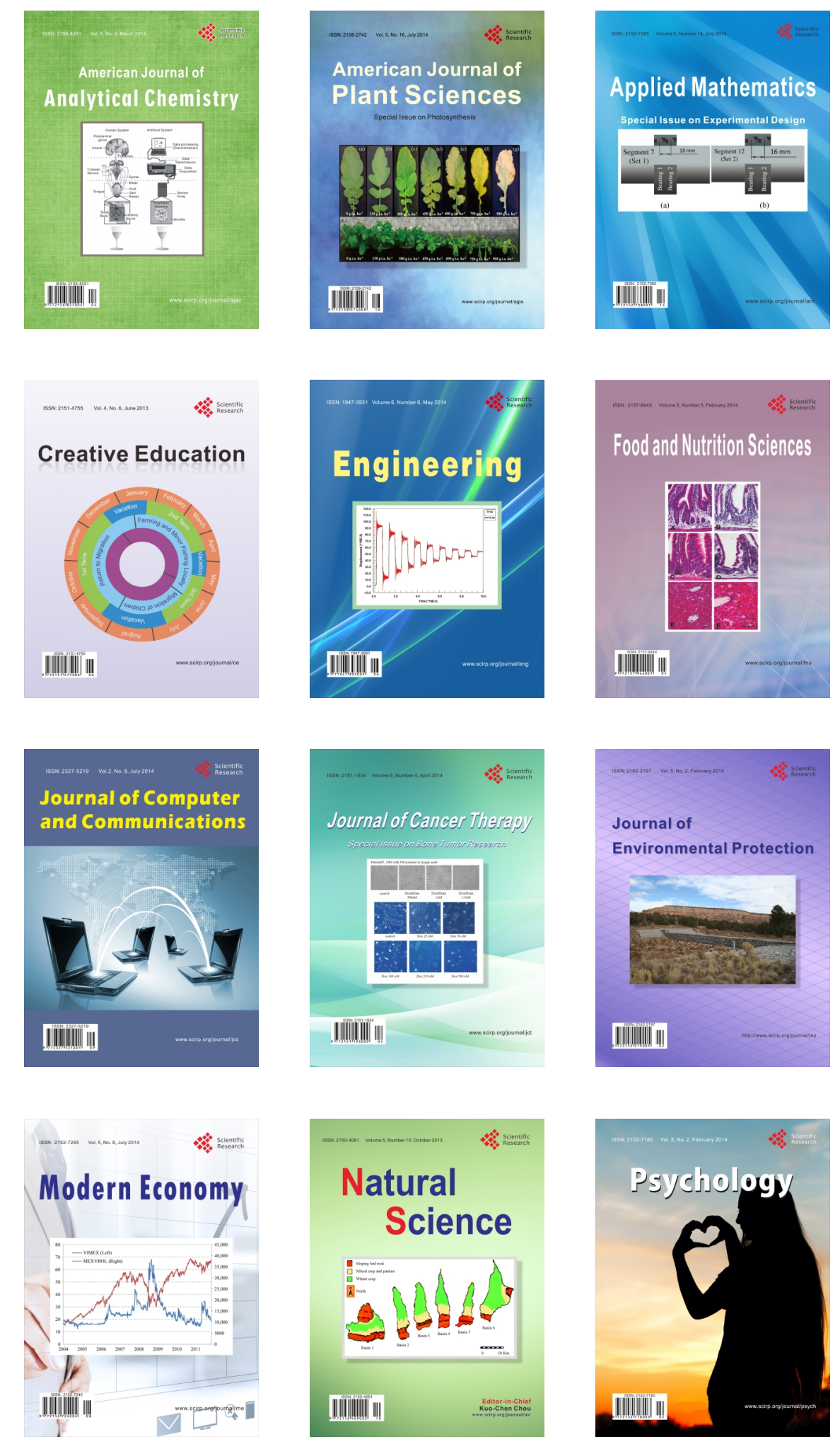